\title{
Auction Winner Legal Protection Execution of Liability for Land Rights in Absentee
}

\author{
Endry Mayuni; Maria Suhita \\ Postgraduate Program, Sebelas Maret University, Indonesia \\ https://doi.org/10.47814/ijssrr.v3i4.57
}

\begin{abstract}
The auction is a public sale by finding the highest price, the auction may be movable items or goods not moving. Determined the winning bidder after the auction officials published a treatise auction that has the strength of evidence is perfect as an authentic deed. In the auction of immovable goods, such as land, the minutes of the auction as proof of deed used for basic transition is done at the land department and spatial / National Land Agency. Related to agricultural land auction participants except there is no restriction in Article 77 point (1) of the Regulation of the Minister of Finance Regulation Number 27 / PMK.06 / 2016 the official auction, husband or wife of the auction officials, officials from the seller, auction guide, judges, prosecutors, clerks, Interpreters confiscation, lawyer / Advocate, Notary, official land deed, appraisers, inspectors DJKN, auction hall employees, and there are opportunities outside the auction winner who makes the land area of the object object absentee land. Ownership of absentee land is prohibited by law because it does not comply with land reform in Indonesia is feared the land is not worked actively, therefore, must be transferred not later than 6 months after the issuance of the certificate to others that one domicile to the object land or or move one subdistrict area with the land object. In Article 3d Government Regulation number 41 of 1964 that the prohibition of transfer of land into an object mengabitkan absentee land. Legal protection The auction winner is causing land object into absente stated in a circular letter of the Supreme Court in 2016 for number 4 in the realm of good faith purchaser.
\end{abstract}

Keyword: Auction; Absentee; Land Protection

\section{A. Preliminary}

Indonesia is a country with a population largely agrarian livelihood in agriculture (agriculture), either as landowners, tenant farmers as well as farm land. Land as a place of trying a very important factor for the survival of society, Everyone needs the land because there is no activity or activities of people who

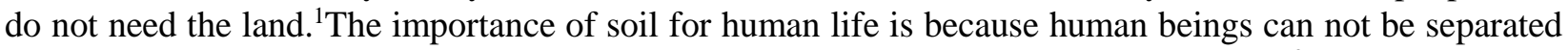
entirely from the ground. They live on the land and obtain food by way of utilizing land. ${ }^{2}$

\footnotetext{
${ }^{1}$ Tampil Anshari Siregar, Mempertahankan Hak Atas Tanah, Medan: Multi Grafik Medan, 2005, p. 2.

${ }^{2}$ G. Kartasapoetra, dkk, Hukum Tanah Jaminan UUPA Bagi Keberhasilan Pendayagunaan Tanah, Jakarta: Bina Aksara,1985,p.1.
} 
Land is an important resource for the community, especially farmers. Farmers who need agricultural land as a means of enhancing agricultural production and efforts to survive. Agricultural land is very important value in a nation, because as one of the pillars of food security in a country.

The importance of soil can be seen in Article 33 paragraph (3) of the Constitution of 1945 (1945) which states "Earth, water and natural resources contained therein controlled by the state and used for the prosperity of the people." Obviously, that land as a place of trying, which is part of the earth's surface should be used as much as possible for the prosperity of the people.

Agricultural land is closely linked to land reform. Land reform is a regulation concerning the ownership of agricultural land by humans. Land Reform Program in Indonesiainclude:

1. Limitation of ownership of land area.

2. Banning titling absente / guntai.

3. The division of the former autonomous region of land outcome of the state land, the land of the results of the maximum limit, the land affected by the ban on absentee / Gunta.

4. The setting about returns and redemption of agricultural lands mortgaged.

5. Rearrangement of revenue-sharing agreements in agricultural land.

6. Determination of the maximum area of agricultural land ownership, along with the prohibition to perform acts that resulted in splitting the ownership of agricultural lands became part are too small.

In reality the land reform program has not been implemented, as can be seen clearly still a lot of parties that dominate agricultural land over a predetermined maximum limit and also have ground outside of domicile residence even many farmers in Indonesia does not have a plot of land for agriculture.

In the agrarian law to know understanding absentee land, the ownership of farmland outside the area subdistrict owner's residence is prohibited by the state, described in Article 7 paragraph (1) a and b Regulation of the Minister of Agrarian and Spatial Planning / Head of National Land Agency No. 182016 on the Control of agricultural land Tenure stating farm owner who resides outside the sub-district where the land lies, within a period of 6 months must transfer their land rights to others in the district where the land lies or move to the district the land lies. And are also described in Article 7 paragraph (2), the provisions of Article 7 paragraph (1) are not met then the land rights will be abolished and will be controlled by the state.

Proof of ownership of land in Indonesia evidenced by a certificate of ownership of the land, and distinguished by kepenguasaannya, namely (1). right of ownership; (2). building rights; (3). operating rights; (4). use rights; (5). rental rights; (6). land rights were temporary.

Land certificate can be used as collateral in a loan agreement between the creditor (creditors) to the debtor (the debtor), which made land certificate as collateral. Guarantee itself by Hartono Hadisoeprapto ${ }^{3}$ is "Everything that is given to creditors to induce the belief that the debtor will fulfill the obligations that can be valued in money arising from an engagement". So that the loan agreement between the creditor and debtor can be realized.

Warranty included in the principal loan agreement, which gave birth to the security rights. Mortgage is a security interest that is charged on land rights as stipulated in Law No. 5 of 1960 on the basic rules of agrarian subjects, following or not following other objects that are installed on the ground, for the repayment of certain debt , which gives precedence to the position of certain creditors to other creditors, ${ }^{4}$

${ }^{3}$ Mariam Darus Badrulzaman, Bab-bab Tentang Credietverband, Gadai dan Fidusia, Bandung : Alumni, 1987, p. 227.

${ }^{4}$ Kansil, Pokok-pokok Hukum Hak Tanggungan Atas Tanah, Jakarta : Pustaka Sinar Harapan, 1997, P. 19. 
In the case of credit agreements is not always the debtor can pay off all debts were passed on, therefore, in accordance with article 6 of Act 4 of 1996 on Mortgage on land and objects relating to the Land (UUHT), said: "If the debtor breach of contract, the first security rights holder has the right to sell the object of mortgage on his own power through a public auction, and take repayment of its receivable from the sale proceeds. " Besides the convenience provided by UUHT for creditors when debtors of mortgage holders in default, pursuant to Article 20 paragraph (1) a and b UUHT guarantee the execution of the object of mortgage can be reached through three (3) ways: ${ }^{5}$

1. parate executie;

2. $\quad$ title exutorial; and

3. Sales under the hand.

Regulation of the finance minister of the republic of Indonesia number 27 / PMK.06 / 2016 on the instructions of the auction in Article 1 (1) states: "The auction is the sale of goods are open to the public at a price quote in writing and / or oral increased or decreased to achieve the highest price, which was preceded by the announcement of the auction. "for the implementation of the auction itself can be carried out in the offices of State assets and auction (KPKNL), which had been scattered in various provinces in Indonesia.

In these modern times, to be able to participate in the auction participate easy enough and does not have to come to the office KPKNL who are conducting the auction, please register on the website KPKNL we can follow the agenda that will runs from auction. In the website provided KPNKL preloaded number of items to be auctioned, such as car-shaped moving goods; motorcycle; jewelry; etc., there is also immovable as land and houses or farmland.

Not a few landowners Agriculture guarantees of security rights. If in future installments performing debtors in installment payments then there is no problem. There was a problem when the time deposits debtor defaults and can not pay off debts to accomplish, then the guarantee is the object of the security rights should be confiscated or were executed under the applicable laws.

Execution Mortgage guarantee of the object can be done in case the debtor has been in default or can not meet its obligations as has been agreed in the credit agreement or deed debtor can not repay the debt even though credit has matured and continued with the execution of mortgage auctions. ${ }^{6}$

After the execution has been completed and will be held the auction, because the elements of the auction is gathering of enthusiasts and the highest sales, droves of enthusiasts from various regions too much to participate, because the community is known term auctioned goods are usually cheaper than the market price. Another problem arises that if the winning bidder is domiciled outside the districts or regencies of ground objects, because under Article 3d Government Regulation No. 41 of 1964 on the change and additional government regulation No. 2241961 explains: "It is forbidden to do any kind of transfer of new rights over agricultural land which resulted in landowners concerned have plots of land outside the District in which he resides".

\section{B. Research Methods}

\footnotetext{
${ }^{5}$ Herowati Poesoko, Parate Executie Obyek Hak Tanggungan (inkonsistensi, Konflik Norma dan Kesesatan Penalaran dalam UUHT), Yogyakarta : Laksbang Pressindo, 2008, P. 8.

${ }^{6}$ Catur Budi Dianawati, "Kajian hukum jaminan dan hak tanggungan yang dilelang tanpa proses permohonan lelang eksekusi ke ketua pengadilan negeri” artikel pada jurnal Akta Hukum, edisi no. 2 vol. 4, Juni 2017, P. 125-132.
} 
This study uses legal research methods. This is a kind of legal research (Doktrinal) ie as legal research (doctrinal research) it involves primary and secondary legal materials, the data were analyzed deductively that originate in a public event, that the truth had been known, or believed, and ends at a conclusion or new knowledge that is more specialized. As well as the interpretative analysis for an explanation of the events that occur based on different perspectives and views from the experts.

\section{Results and Discussion}

\section{Prohibition of Absentee Land Ownership}

Ownership of agricultural land by absentee / Guntai is landholdings Located outside the residence owners, such as different regions or districts. In the absentee land law provisions must transfer their land rights within a period of 6 months to others in the district of the place where the land or its owners moved to other districts. Absentee land ownership ban for violating the principle inArticle 7 paragraph (1) a and $b$ Regulation of the Minister of Agrarian and Spatial Planning / Head of National Land Agency No. 182016 which states that agricultural land should be done or actively cultivated by the owner himself. Similarly, the principle of the prohibition of ownership and control of land which exceed the limits in an effort to prevent the accumulation of land in the hands of certain groups only, as well as a ban on land abandoned. But in reality there are still many people who own agricultural land in the land of absentee and aggressors, and abandon their land. Given that Article 10 BAL public interest, then the juridical provisions of this article included in the legal provisions that force or "dwingend recht".?

Article 3d PP 224/1961 jo. PP 41/1964 describes the prohibition of all forms of transfer of agricultural land to people who are outside of the subdistrict, which cause become absentee land. From the article also expressly ban on the absentee land.

According to Boedi Harsono, the purpose of the ban on absentee land ownership is for the results obtained from the exploitation of the land was largely enjoyed by the rural communities where land is concerned, because the land owner will reside producing areas. Ownership of agricultural land by absentee / guntai this, causing inefficient cultivation, for example on the implementation, supervision, and transport of the results. This means that the peasant land belonging to others with all his strength, his responsibility and all the risks, but only received part of the results of management. On the other hand, land owners who are away from the lay of the land and do not work the land without incurring any risk and without removing her sweat will get a bigger share of the results of the soil.

So that, it is not in accordance with the purpose of land reform, held in Indonesia, namely to enhance the income and standard of living of farmers tilling the ground and as the foundation or the requirements for organizing economic development towards a just and prosperous society based on Pancasila. To clarify the absentee land, it can be said that the terms of entry into force of the ban on absentee land ownership based on their legal events that can cause absentee ownership, such as: ${ }^{8}$

a. Farm owner who left sub- location of the land.

b. A person who receives the inheritance of agricultural land are located in other districts.

\footnotetext{
${ }^{7}$ M. Sukran Lubis ,2012. “Larangan pemilikan tanah secara absentee” http://syukranlubis.blogspot.com accessed on February 1, 2019.

${ }^{8}$ Harsono, B., Hukum Agraria Indonesia. Jakarta: Penerbit Djembatan. 2008.
} 
c. All forms of transfer of property rights on agricultural land such as buying and selling, donation and exchange.

\section{Legal Protection in Absentee Land Auction Winner}

Sales of goods made open to the public, is one element of the auction, and therefore the auction participants is open to the entire community, not everyone can be an auction participant for in Article 77 point (1) The Minister of Finance Regulation No. 27 / PMK.06 / 2016 explained that the parties are prohibited from joining the auction, the official auction, husband or wife officials of the auction, officials sellers, guides auction, Judge, Prosecutor, Registrar, Bailiffs, lawyer / Advocate, Notary, official land deed, appraisers, inspectors DJKN, servants hall auction, auction officials and office clerks class II associated directly with the auction process.

In the execution of the security rights of the auction in the form of agricultural land is also open to the public, there are no rules restricting the auction participants except under Article 77 of the Financial Candy 27 / PMK.06 / 2016, and the winning bidder would open opportunities for which are outside the area of the object of the auction.

Regarding security rights limits auction participants, according to Lili Warsito ${ }^{9}$ difficult when the land auction is restricted to one single district area, as in the security rights include the right of creditors to be met, namely repayment of the loan borrowed by the debtor, therefore confiscated the stretcher right and then in the auction. The difficulty of the auction that is limited to a single district area is if the lack of interest or the area that includes the majority of middle and lower class, concern the absence of the winning bidder at an auction of the land.

Having determined the winner land auction, auction officials later published Proceedings of the auction which later formed the basis for the transition is done in the office ATR / BPN and categorized switchover Purchase.

Land has an important role for human life because human life can not be separated from land. ${ }^{10}$ The basic concept of the right to control the land by the state in Indonesia contained in Article 33 paragraph (3) of the Act of 1945, hereinafter referred to as the 1945 Constitution which reads: Earth and water and natural resources contained in it are controlled by the state and used for the welfare of the people. Prior to the 1945 amendments, Article 33 paragraph (3) are described in the explanation of Article 33 paragraph 4, which reads: "The earth and water and natural resources contained therein are highlights prosperity of the people. Therefore it should be controlled by the state and used for -great prosperity of the people ". ${ }^{11}$ Therefore absentee land ownership inactive feared could affect agricultural land and can hinder people's welfare. On the basis of absentee land ownership is prohibited as incompatible with the applicable landrefrom, therefore published BAL in order to control the ownership of land.

The land is public property, the assets of the people, the nation's assets, farmers are businessmen, so that the soil is an important asset for his farming business, therefore BAL made is made for the government / State led the use of land and regulate land rights, since such arrangements influential on revenue and welfare. ${ }^{12}$

\footnotetext{
${ }^{9}$ Results of interviews with Notary and PPAT of Klaten "Mr. Lilik Warsito" on 22 January 2019 at 16:00 pm

${ }^{10}$ Nurwati \& risnawati, A.S, urgensi pengukuran ulang batas kepemilikan di BPN Kabupaten magelang, artikel pada jurnal Varia Justicia, edisi no.11. Vol (1), 2015, P. 66.

${ }^{11}$ M. Bakri, hak menguasai tanah oleh negara (paradigma baru untuk reforma agraria), Bandung: Citra media, 2007.

${ }^{12}$ Djanggih, H \& Salle, 2017, aspek hukum pengadaan tanah bagi pelaksanaan pembagunan untuk kepentingan umum, artikel pada jurnal Pandecta Research law, edisi no. 12, vol (2), P. 165.
} 
With BAL issued absentee land ownership is forbidden, because of the transition of all kinds that cause absentee land is prohibited, but there are Exceptions described in Article 8 of the Regulation of the Minister of Agrarian and Spatial number 18 in 2016, namely:

a. Landowning his district directly adjacent to the land.

b. $\quad$ The land owner who was on state business.

c. Landowners who were performing the duties of religion.

d. Servants, military officials, and that is equivalent to them.

e. Other provisions determined by the Minister.

Protection to buyers who are acting in good faith contained in the circular letter of the Supreme Court of the Republic of Indonesia Number 42016 letter B. Formulation Room General Civil Law, number 4 is mentioned criteria for buyers of good faith that must be protected in accordance with Article 1338, paragraph 3 of the Civil Code, namely:

a. Buying and selling in accordance with the procedures and accompanied with valid documents by law, one of them is doing purchases by public auction.

b. Doing prudence by researching things berkatian with the contracted land object, include:

- $\quad$ Seller is a person who has a right to the land, and can be proven.

- $\quad$ Land is the object of selling is not in foreclosure status, or guarantee the security rights.

- $\quad$ To land that has been bersertipikat has received information from the ATR / BPN and history of the land legal relationship between the holder of the certificate.

According to Bambang Jentot Sugiyanto ${ }^{13}$ Different agricultural land transition area due for auction and has been published treatise could be published the certificate auction, but with the provision stampel within a period of 6 months should be transferred to another person who domicile same as the object or objects to move to the district the land lies. In the exercise of control of absentee land is hard to do, because monitoring is difficult, and it takes a lot of time and as well as the many in need, as well as the special committee should be set up to enforce these rules, and over here the National Land Agency districts klaten have never curb soil absentee. Absentee land ownership was given time for 6 months according to instructions Agrarian Ministry Regulation No. 182016 Article 7, paragraph 1.

Protection against the winner of the auction that led to sales events for the minutes of the auction in accordance with Article 7, paragraph 1 Regulation of the Minister of Agrarian No. 182016 that describes the certificates issued since 6 months should be immediately diverted to another party who is still a resident or landowner moved kedomisili the ground objects. There is another solution that is by changing the status of agricultural land to garden soil.

\section{Conclusion}

1. Absentee land ownership had been clearly prohibited by law because it does not comply with land reform in Indonesia, where agricultural land should be done with the active. And in article 7 paragraph 1 of article Agrarian Ministry Regulation No. 182016 that describes the certificates issued since 6 months

\footnotetext{
${ }^{13}$ According to interviews with the Land Planning Section Head of BPN Klaten "Mr. Jentot Bambang Sugiyanto" on February 15, 2019 at $10.00 \mathrm{hrs}$
} 
should be immediately diahlihkan to another party who is still a resident or landowner moved kedomisili the ground objects, as well as in Article 3d PP 224/1961 jo. PP 41/1964 explains that the forbidden transition of agricultural land is not a domicile with the land object.

2. Elements of the auction is open to the public, unless the parties are prohibited from joining the auction in accordance with Article 77 point (1) The Minister of Finance Regulation No. 27 / PMK.06 / 2016, open to opportunities outside the auction winner of the land objects. The protection afforded by the law after being issued a certificate that is moved to another object or one object domicile move to the ground and is also contained in the circular letter of the Supreme Court nomo4 42016 for buyers in the domain of good faith. Another solution could be reached by transforming the status of agricultural land into garden soil, as long as the agricultural land into residential or industrial zone, which is where ownership of the yard is not constrained by the rules of absentee land.

\section{Suggestion}

1. Rules about absentee land is a product of the rule of the 1960s where many lands legacy after Dutch colonial much neglected and therefore published BAL as the cornerstone of reform which has the function of the equitable distribution of land and the function of land use, in modern times these provisions should much adapted to this era where technology is already highly developed transportation and processing technology of agricultural land is also growing.

2. Absentee land ownership and legal events since the owner should be looked into, especially land ownership stems from the way of acquisition as auction encumbrance or inheritance.

\section{Bibliography}

Anshari Siregar, Tampil. 2005. Mempertahankan Hak Atas Tanah. Medan: Multi Grafik Medan.

G. Kartasapoetra, dkk. 1985. Hukum Tanah Jaminan UUPA Bagi Keberhasilan Pendayagunaan Tanah, Jakarta: Bina Aksara.

Badrulzaman, Mariam Darus. 1987. Bab-bab Tentang Credietverband, Gadai dan Fidusia, Bandung: Alumni.

Kansil. 1997. Pokok-pokok Hukum Hak Tanggungan Atas Tanah, Jakarta : Pustaka Sinar Harapan.

Poesoko, Herowati. 2008. Parate Executie Obyek Hak Tanggungan (inkonsistensi, Konflik Norma dan Kesesatan Penalaran dalam UUHT), Yogyakarta : Laksbang Pressindo.

Dianawati , Catur Budi. 2017. "Kajian hukum jaminan dan hak tanggungan yang dilelang tanpa proses permohonan lelang eksekusi ke ketua pengadilan negeri" artikel pada jurnal Akta Hukum, edisi no. 2 vol. 4.

Harsono, B. 2008. Hukum Agraria Indonesia. Jakarta: Penerbit Djembatan.

M. Bakri, 2007. hak menguasai tanah oleh negara (paradigma baru untuk reforma agraria), Bandung: Citra media. 
Djanggih, H \& Salle, 2017, aspek hukum pengadaan tanah bagi pelaksanaan pembagunan untuk kepentingan umum, Artikel pada jurnal Pandecta Research law. edisi no. 12, vol (2).

Nurwati \& risnawati, A.S, 2015, urgensi pengukuran ulang batas kepemilikan di BPN Kabupaten magelang, artikel pada jurnal Varia Justicia. no.11. Vol (1).

Lubis, M. Sukran, 2012. "Larangan pemilikan tanah secara absentee" : http://syukranlubis.blogspot.com diakses tanggal 1 Februari 2019.

\section{The Legislation:}

Undang-undang dasar 1945

Undang-undang nomor 5 tahun 1960 tentang Peraturan Dasar Pokok-Pokok Agraria.

Undang-undang No.4 Tahun 1996 tentang Hak Tanggungan Atas Tanah Beserta Benda-benda yang berkaitan dengan Tanah

Peraturan Menteri Keuangan Republik Indonesia Nomor 27/PMK.06/2016 Tahun 2016 Tentang Petunjuk Pelaksanaan Lelang.

Peraturan Pemerintah nomor 224 tahun 1961 tentang pelaksanaan Pembagian Tanah dan Pemberian Ganti Kerugian.

Peraturan Menteri Agraria dan Tata Ruang / Kepala Badan Pertanahan Nasional nomor 18 tahun 2016 tentang pengendalian penguasaan tanah pertanian.

Peraturan Pemerintah nomor 41 tahun 1964 tentang perubahan dan penambahan aturan peraturan pemerintah nomor 224 tahun 1961 tentang pelaksanaan Pembagian Tanah dan Pemberian Ganti Kerugian.

Surat edaran nomer 4 tahun 2016 tentang pemberlakuan hasil rapat pleno kamar mahkamah agung tahun 2016 sebagai pedoman pelaksanaan tugas bagi pengadilan.

\section{Copyrights}

Copyright for this article is retained by the author(s), with first publication rights granted to the journal.

This is an open-access article distributed under the terms and conditions of the Creative Commons Attribution license (http://creativecommons.org/licenses/by/4.0/). 